Agnieszka Stawiszyńska

Uniwersytet Marii Curie-Skłodowskiej w Lublinie

\title{
Gender mainstreaming w Europejskim Funduszu Społecznym w Polsce po 2007 roku
}

-1 uropejski Fundusz Społeczny (EFS) jest najstarszym funduszem strukturalnym Unii Europejskiej. Podstawą formalną jego stworzenia był jeden z traktatów rzymskich z 1957 roku, ustanawiający Europejską Wspólnotę Gospodarczą (EWG). W artykule 123 tego traktatu wskazano, iż:

w celu poprawy możliwości zatrudniania pracowników w ramach rynku wewnętrznego i przyczyniania się w ten sposób do podniesienia poziomu życia, ustanawia się [...] Europejski Fundusz Społeczny; dąży on do ułatwienia zatrudniania pracowników i zwiększania ich mobilności geograficznej i zawodowej wewnątrz Wspólnoty¹.

Obecnie Europejski Fundusz Społeczny jest głównym unijnym instrumentem finansowym służącym do wspierania kapitału ludzkiego w obszarach edukacji i rynku pracy. Jedną z zasad jego wdrażania jest równość szans kobiet i mężczyzn. Jak wskazuje Rozporządzenie (WE) nr 1081/2006 Parlamentu Europejskiego i Rady z dnia 5 lipca 2006 roku w sprawie Europejskiego Funduszu Społecznego i uchylające rozporządzenie (WE) nr 1784/1999:

państwa członkowskie i Komisja mają zapewnić, że wprowadzanie w życie priorytetów finansowanych z EFS w ramach celów: Konwergencja oraz Konkurencyjność regionalna i zatrudnienie przyczynia się do wspierania równości oraz zniesienia nierówności między kobietami a mężczyznami. Podejściu polegającemu na włączaniu problematyki równości płci do głównego nurtu polityki (gender mainstreaming) powinny towarzyszyć konkretne działania w celu zwiększenia trwałego udziału kobiet w zatrudnianiu oraz rozwoju ich kariery.

Gender mainstreaming jest strategią Unii Europejskiej, która ma na celu wprowadzenie równości szans dla kobiet i mężczyzn w instytucjach, organizacjach i polityce. Strategia gender mainstreaming została uwzględniona, zgodnie z rozporządzeniem Komisji Europejskiej, w Traktacie amsterdamskim z 1997 roku i jest wiążąca dla wszystkich państw członkowskich. Definicja gender mainstreaming sformułowana przez Radę Europy brzmi: „Gender

${ }^{1}$ Traktat ustanawiający Europejską Wspólnotę Gospodarczą, Rzym, 25 marca 1957. 
mainstreaming polega na (re)organizacji, poprawie, rozwoju i ewaluacji procesów decyzyjnych po to, aby umożliwić osobom obojga płci biorącym udział w życiu politycznym równoważne spojrzenie na kobiety i mężczyzn we wszystkich dziedzinach i na wszystkich płaszczyznach"2.

W okresie przygotowawczym do cyklu 2007-2013 środki Europejskiego Funduszu Społecznego w Polsce zostały ulokowane w jednym programie operacyjnym pod nazwą Program Operacyjny Kapitał Ludzki (PO KL). Wartość ogólna PO KL to ponad 11,4 mld euro, przy czym wkład finansowy Europejskiego Funduszu Społecznego wyniósł ponad 9,7 mld euro. Pozostałe środki, tj. ponad 1,7 mld euro, stanowią wkład krajowy. W ramach PO KL ok. 60 proc. środków przeznaczono na realizację wsparcia regionalnego, natomiast 40 proc. środków skierowano na realizację wsparcia sektorowego na szczeblu centralnym. Polska, podobnie jak pozostałe kraje członkowskie UE, została zobowiązana do włączenia kwestii genderowych w zasady wdrażania Europejskiego Funduszu Społecznego. W PO KL wskazano, iż „zasada gender mainstreaming będzie wdrażana na każdym etapie realizacji programu" ${ }^{3} . \mathrm{Na}$ etapie programowania pod uwagę wzięta została odmienna sytuacja kobiet i mężczyzn na rynku pracy. Jako kluczowe dla interwencji EFS w kontekście równości szans kobiet i mężczyzn w ramach PO KL wskazano:

- konieczność zwiększania zatrudnienia kobiet i mężczyzn, w tym zwłaszcza kobiet, jako tej grupy, która jest w szczególnie trudnej sytuacji na rynku pracy;

- podnoszenie kwalifikacji zawodowych kobiet i mężczyzn, w tym w szczególności wsparcie osób o niskich i zdezaktualizowanych kwalifikacjach, np. kobiet powracających na rynek pracy po urlopach macierzyńskich i wychowawczych;

- rozwijanie aktywności ekonomicznej kobiet i mężczyzn jako odpowiedzi na wyzwania rynkowe, pobudzanie postaw przedsiębiorczych;

- godzenie życia zawodowego i prywatnego poprzez zwiększanie dostępu do usług opiekuńczych nad dziećmi i osobami zależnymi, co umożliwi pełne uczestnictwo w kształceniu i rynku pracy oraz promowanie nowych form organizacji pracy ${ }^{4}$.

Zasada równości szans kobiet i mężczyzn została w programie uznana za zasadę horyzontalną, tj. przekrojową dla wszystkich priorytetów. Ponadto wskazano na konieczność promowania rozwiązań systemowych sprzyjających upowszechnianiu zasady równości szans kobiet i mężczyzn. Priorytet I w ramach PO KL wprowadził działania skierowane na tworzenie systemowych rozwiązań na rzecz równych szans, godzenia życia prywatnego i zawodowego, mobilności i przekwalifikowań, jak również promowania

${ }^{2}$ Gender Mainstreaming. Conceptual Framework, Methodology and Presentation of Good Practices, Council of Europe, Strasburg 1998, s. 15.

3 Program Operacyjny Kapitat Ludzki. Narodowe Strategiczne Ramy Odniesienia 2007-2013, Ministerstwo Rozwoju Regionalnego, Warszawa 2007, s. 144.

4 Ibidem, s. 152. 
równych szans kobiet i mężczyzn na rynku pracy oraz zwalczania stereotypowego postrzegania ról kobiecych i męskich w życiu zawodowym i społecznym. W ramach priorytetu II przewidziano realizację działań na rzecz wspierania i upowszechniania wśród przedsiębiorstw, w tym wśród zarządzających zasobami ludzkimi, idei równych szans kobiet i mężczyzn, tworzenia zachęt do opracowywania planów na rzecz równości płci i zarządzania różnorodnością w miejscu pracy. W ramach priorytetów regionalnych (priorytety VI-IX), zaplanowano działania zwiększające szanse na uzyskanie zatrudnienia, wejście na rynek pracy i podnoszenie kwalifikacji zawodowych. Szczególny nacisk postanowiono położyć na zwiększanie zatrudnienia wśród kobiet, które - jak wykazała diagnoza - są grupą defaworyzowaną na rynku pracy ${ }^{5}$.

PO KL jest wdrażany poprzez realizację projektów, wybieranych w dwóch trybach: konkursowym i systemowym. Zgodnie z zapisami programu przygotowywane projekty muszą być oparte o diagnozę uwzględniającą sytuację kobiet i mężczyzn w danym obszarze i ocenę ich wpływu na sytuację płci (gender impact assessment). Program wprost wskazuje, iż „każdy projekt realizowany w ramach PO KL zawierać będzie opis oceny wpływu na sytuację płci”'. Celem owego działania jest ocena stopnia oddziaływania zgłaszanych projektów na sytuację kobiet i mężczyzn w obszarach problemowych, aby zapobiec występowaniu jakichkolwiek przejawów nierówności czy dyskryminacji. Analiza zapisów wniosku o dofinansowanie projektu, dokonywana przez członków komisji oceniającej, ma weryfikować, czy projekt rzeczywiście uwzględnia odmienne potrzeby kobiet i mężczyzn, na przykład poprzez oferowanie zindywidualizowanych form wsparcia. Zapisy PO KL wskazują również, iż ocena merytoryczna, odnosząca się do jakości projektu, będzie uwzględniała przedstawioną analizę i - co ważniejsze - opis wpływu na sytuację kobiet i mężczyzn. Program wskazuje na dwutorową klasyfikację projektów:

- „projekty pozytywne, które przewidują specyficzne działania nakierowane na zwalczanie istniejących nierówności pomiędzy kobietami i mężczyznami”;

- „projekty równościowe, które w sposób ogólny przyczyniają się do zapewnienia równości płci”’.

Program opisuje również sposób włączenia kwestii genderowych do etapów monitorowania, sprawozdawczości i ewaluacji. W kontekście monitorowania i sprawozdawczości wytyczne odnoszą się do systemu wskaźników, które muszą umożliwiać gromadzenie i zbieranie danych statystycznych w podziale na płeć. W kontekście ewaluacji natomiast wskazuje się na

\footnotetext{
${ }^{5}$ Ibidem.

${ }^{6}$ Ibidem.

7 Ibidem, s. 153.
} 
konieczność badania oddziaływania programu na realizację zasady równych szans kobiet i mężczyzn. W programie zaznaczono również, iż dane pochodzące z systemu informatycznego pozwolą na systematyczne i kompleksowe prowadzenie badań ewaluacyjnych pod kątem wsparcia udzielanego w podziale na płeć, monitorowania dalszych losów uczestników, a także efektywności udzielonej im pomocy z uwzględnieniem podziału na płeć ${ }^{8}$.

Warto podkreślić, że jakkolwiek opisane wyżej kwestie zawarte były w programie od samego początku. W praktyce jednak zdecydowana większość projektów z lat 2007-2008 nie kładła nacisku na kwestie genderowe. Dlatego też w kwietniu 2009 roku Ministerstwo Rozwoju Regionalnego, pełniące rolę Instytucji Zarządzającej Europejskim Funduszem Społecznym w Polsce, wprowadziło standard minimum równości szans kobiet i mężczyzn w projektach EFS. Standard minimum przybrał formę sześciu pytań zawartych we wstępnej części Karty Oceny Merytorycznej. Brzmiały one następująco:

1. Czy uzasadnienie potrzeby realizacji projektu zawiera analizę sytuacji kobiet i mężczyzn, która wskazuje na nierówności ze względu na płeć? (punkt 3.1 wniosku o dofinansowanie)

2. Czy analiza sytuacji kobiet i mężczyzn zawarta w uzasadnieniu potrzeby realizacji projektu, zawiera dane ilościowe, które wskazują na brak istniejących nierówności w obszarze problemowym projektu? (punkt 3.1 wniosku o dofinansowanie)

3. Dane w podziale na płeć użyte w uzasadnieniu potrzeby realizacji projektu dotyczą zasięgu i obszaru interwencji projektu? (punkt 3.1 wniosku o dofinansowanie)

4. Działania podejmowane w projekcie odpowiadają na nierówności lub bariery ze względu na płeć, istniejące w obszarze problemowym projektu lub różnicują działania (formy wsparcia) dla kobiet i mężczyzn, przyczyniając się do zmniejszenia istniejących nierówności w obszarze projektu? (punkt 3.3 wniosku o dofinansowanie)

5. Rezultaty są podane w podziale na płeć i wynikają z uzasadnienia potrzeby realizacji projektu. Rezultaty wskazują, jak projekt wpłynie na sytuację kobiet i mężczyzn w obszarze projektu? (punkt 3.4 wniosku o dofinansowanie)

6. Projekt przewiduje równościowy sposób zarządzania projektem? (punkt 3.5 wniosku o dofinansowanie) ${ }^{9}$.

W kwietniu MRR przedstawiło dokument Podręcznik przygotowania wniosków o dofinansowanie projektów $w$ ramach $P O K L$. Podręcznik miał pełnić rolę materiału pomocniczego tak dla projektodawców przy wypełnianiu wniosku, jak i dla osób oceniających projekty. Stwierdzenie, czy projekt jest zgodny z zasadą równości szans kobiet i mężczyzn odbywało się podczas oceny merytorycznej. Członkowie Komisji Oceny Projektów zobowiązani byli do udzielenia pisemnej odpowiedzi na wszystkie pytania odnoszące się do standardu. Nieuzyskanie dwóch pozytywnych odpowiedzi w tej właśnie

\section{Ibidem.}

${ }^{9}$ Zasady dokonywania wyboru projektów w ramach Programu Operacyjnego Kapitał Ludzki z dnia 1 kwietnia 2009 roku, Ministerstwo Rozwoju Regionalnego, Warszawa 2009, s. 114-115. 
części oceny (tzw. ocena spełniania standardu minimum) było równoznaczne z odrzuceniem wniosku (w przypadku projektów konkursowych) lub zwróceniem do uzupełnienia (w przypadku projektów systemowych). Jak wskazano w poradniku z 2009 roku, zamysłem Instytucji Zarządzającej PO KL było zwiększanie liczby pozytywnych odpowiedzi wymaganych do spełnienia standardu minimum od roku $2010^{10}$.

Podręcznik przygotowania wniosków o dofinansowanie projektów $w$ ramach $P O K L$ zawierał wskazówki na temat sposobu wypełniania wniosku z uwzględnieniem zapisów koniecznych do spełnienia standardu minimum. $\mathrm{W}$ odniesieniu do pytania pierwszego ze standardu minimum poradnik zalecał umieszczanie w punkcie 3.1 wniosku, tj. w uzasadnieniu realizacji projektu, analizy uwzględniającej społeczno-kulturowe uwarunkowania płci. Analiza taka powinna ujawniać różnice między położeniem kobiet i mężczyzn w danym obszarze problemowym i być oparta na danych ilościowych i/lub jakościowych. Ponadto instrukcja wskazywała, iż cele projektu powinny przyczyniać się do rozwiązywania kwestii nierówności określonych $\mathrm{w}$ analizie problemu.

W odniesieniu do pytania drugiego instrukcja wskazywała, iż wykazanie w analizie sytuacji kobiet i mężczyzn braku nierówności w obszarze problemowym, którego dotyczy projekt nie oznacza automatycznego zwolnienia ze spełniania standardu minimum. Brak nierówności między płciami musiał bowiem zostać wykazany na podstawie danych ilościowych i/lub jakościowych, które byłyby w pełni weryfikowalne dla członków Komisji Oceny Projektów. Jednocześnie wskazano, iż pytanie nr $2 \mathrm{w}$ większym stopniu będzie mieć zastosowanie przy projektach systemowych, tj. skierowanych do systemów i struktur, niż przy projektach skierowanych do osób.

Aby uzyskać pozytywną ocenę w trzecim pytaniu, wykazane we wniosku dane ilościowe w podziale na płeć musiały dotyczyć zasięgu realizacji projektu, na przykład danej instytucji, gminy, regionu, jak również obszaru interwencji, tj. danej branży czy sektora. Poradnik jednoznacznie wskazywał, iż dane, które nie będą odnosić się do zdiagnozowanych problemów i celów projektu, nie będą uprawniać do uzyskania pozytywnej odpowiedzi.

W odniesieniu do pytania czwartego poradnik wskazywał, iż zaplanowane działania powinny odpowiadać na nierówności i bariery dotyczące kobiet i mężczyzn zdiagnozowane $\mathrm{w}$ analizie sytuacji problemowej i różnić się w kontekście odmiennych potrzeb kobiet i mężczyzn. Ponadto poradnik zalecal, aby w projektach, w których nie zdiagnozowano nierówności,

${ }^{10}$ Podręcznik przygotowania wniosków o dofinansowanie projektów $w$ ramach PO KL z dnia 1 kwietnia 2009 roku, Ministerstwo Rozwoju Regionalnego, Warszawa 2009, S. $100-101$. 
wnioskodawca przewidział działania zmierzające do przestrzegania zasady równości szans kobiet i mężczyzn na wszystkich etapach realizacji.

Pytanie piąte ze standardu minimum, odnoszące się do rezultatów projektu, opatrzono uwagą, iż zapewnienie dostępu 50 proc. kobietom i 50 proc. mężczyznom w projekcie nie jest realizacją zasady równościowej. Powyższa uwaga była między innymi wynikiem często stosowanego przez projektodawców podziału 50/50 jako, w ich opinii, modelowego dla wykazania działań równościowych. W instrukcji podkreślono również, iż w punkcie 3.4 wniosku powinna znaleźć się informacja, w jaki sposób rezultaty przyczyniają się do zmniejszenia istniejących nierówności ze względu na płeć w obszarze projektu.

W nawiązaniu do ostatniego pytania poradnik rekomendował, aby w punkcie 3.5 wnioskodawca zawarł informację, w jaki sposób będzie przestrzegał zasady równości szans kobiet i mężczyzn w zarządzaniu projektem. Opis ten był wymagany szczególnie w stosunku do projektów badawczych, skierowanych do instytucji, gdzie zalecano na przykład organizację prac projektowych w sposób wspierający godzenie życia rodzinnego z zawodowym ${ }^{11}$.

Jednocześnie wprowadzono wyjątki, co do których standard minimum miał nie mieć zastosowania. I tak, ze stosowania standardu minimum wyłączono projekty o ograniczonej rekrutacji, która mogła wynikać z:

1. profilu działalności projektodawcy (ograniczenia statutowe);

2. realizacji działań pozytywnych (działania pozwalające wpłynąć na niekorzystną sytuację danej płci w konkretnym obszarze, a tym samym wyrównanie jej szans społecznych i zawodowych);

3. zakresu realizacji projektu (np. na terenie zakładu karnego) ${ }^{12}$.

Pomimo że do spełnienia standardu minimum wymagane było uzyskanie jedynie dwóch odpowiedzi pozytywnych na sześć pytań, okazało się to niezwykle trudnym zadaniem dla projektodawców. Brak uwzględniania kwestii płci w składanych wnioskach powodował odrzucanie wielu projektów w związku z niespełnianiem przez nie standardu minimum. Dlatego też z początkiem 2010 roku Ministerstwo nie tylko nie zdecydowało się na zwiększenie liczby wymaganych pozytywnych odpowiedzi, ale również dokonało zmian znacznie liberalizujących brzmienie standardu. Znaczącą zmianą było usunięcie z pytań wskazania punktu we wniosku, w którym musiały być zawarte dane informacje. W praktyce oznaczało to, że jeśli dana informacja była zawarta w którejkolwiek z części wniosku, powinna być uznana przez oceniających jako spełnienie wymagań. Ponadto pewnym

\footnotetext{
${ }^{11}$ Ibidem.

${ }_{12}$ Zasady dokonywania..., op. cit., s. 115 .
} 
modyfikacjom uległo brzmienie samych pytań. Pytania standardu minimum obowiązujące od 2010 roku brzmią następująco:

1. Czy projekt zawiera analizę sytuacji kobiet i mężczyzn dotyczącą obszaru interwencji i/lub zasięgu oddziaływania projektu, która wskazuje na nierówności ze względu na płeć?

2. Czy analiza sytuacji kobiet i mężczyzn zawiera dane ilościowe, które wskazują na brak istniejących nierówności w obszarze interwencji i/lub zasięgu oddziaływania projektu?

3. Czy użyte w analizie sytuacji kobiet i mężczyzn dane w podziale na płeć dotyczą obszaru interwencji i zasięgu oddziaływania projektu?

4. Czy działania odpowiadają na nierówności ze względu na płeć istniejące w obszarze interwencji i/lub zasięgu oddziaływania projektu i/lub różnicują działania (formy wsparcia) dla kobiet i mężczyzn?

5. Czy rezultat(y) są podane w podziale na płeć i/lub wskazują jak projekt wpłynie na sytuację kobiet i mężczyzn w obszarze interwencji i/lub zasięgu oddziaływania projektu?

6. Czy projekt wskazuje, w jaki sposób zostanie zapewnione równościowe zarządzanie projektem? ${ }^{13}$

Zmianie uległa również kwestia wyłączania projektów ze standardu minimum. Od 1 stycznia 2010 roku do wyjątków, co do których nie stosuje się standardu minimum, należą:

1. profil działalności projektodawcy (ograniczenia statutowe);

2. realizacja działań pozytywnych (działania, które pozwalają wpłynąć na niekorzystną sytuację danej płci w konkretnym obszarze interwencji i zasięgu oddziaływania projektu, a tym samym wyrównanie jej szans społecznych i zawodowych);

3. zamknięta rekrutacja (projekt obejmuje wsparciem - ze względu na zakres swojego oddziaływania - wszystkich pracowników/personel konkretnego podmiotu, wyodrębnionej organizacyjnie części danego podmiotu lub konkretnej grupy podmiotów wskazanych we wniosku o dofinansowanie) $)^{14}$.

$\mathrm{Z}$ dniem 1 stycznia 2010 roku do instrukcji wypełniania wniosku o dofinansowanie realizacji projektu wprowadzono również jako dodatkowy element instrukcję wypełnienia wniosku w kontekście standardu minimum realizacji zasady równości szans kobiet i mężczyzn w PO KL. Instrukcja ta jednoznacznie nałożyła na wnioskodawców obowiązek udowodnienia, że wniosek spełnia standard minimum, tj. we wniosku o dofinansowanie projektu muszą być zawarte informacje niezbędne do określenia, czy standard został spełniony ${ }^{15}$. Instrukcja doprecyzowuje również rozumienie wyjątków od standardu minimum. Wyłączenie ze względu na profil działalności projek-

${ }^{13}$ Zasady dokonywania wyboru projektów w ramach Programu Operacyjnego Kapitat Ludzki z dnia 1 stycznia 2010 roku, Ministerstwo Rozwoju Regionalnego, Warszawa 2010, S. 119-120.

14 Ibidem.

15 Wniosek o dofinansowanie projektu: Program Operacyjny Kapitat Ludzki. Instrukcja (Instrukcja do wniosku o dofinansowanie v 5·3.1), Ministerstwo Rozwoju Regionalnego, 
todawcy jest możliwe tylko wówczas, jeśli w statucie organizacji (lub innym równoważnym dokumencie) istnieje wyraźny zapis, ograniczający działania instytucji tylko do jednej z płci i wnioskodawca zawrze we wniosku taką informację. Statut organizacji jest przed podpisaniem umowy weryfikowany. Wyjątek odnoszący się do działań pozytywnych może być uwzględniony, jeśli istnieje potrzeba skierowania projektu tylko do jednej płci. Działanie takie musi być wynikiem gorszego położenia danej płci w obszarze interwencji i/lub zasięgu oddziaływania projektu oraz być uzasadnione $\mathrm{w}$ analizie sytuacji kobiet i mężczyzn. Aby można było uznać, iż projekt jest wyjątkiem ze względu na zamkniętą rekrutację, wnioskodawca powinien wymienić, podając indywidualną nazwę, podmiot lub podmioty, do których skierowane jest wsparcie w ramach projektu ${ }^{16}$.

Instrukcja z 2010 roku w dużej mierze zliberalizowała wymagania co do minimalnych informacji zawartych we wniosku o dofinansowanie projektu, umożliwiających pozytywną odpowiedź na pytania ze standardu minimum. I tak, dla pytania pierwszego jako minimalny wymóg wskazano podanie $\mathrm{w}$ analizie sytuacji kobiet i mężczyzn tylko jednej danej w podziale na płeć, a dotyczącej obszaru interwencji i/lub zasięgu oddziaływania projektu. Dla wykazania braku nierówności pomiędzy kobietami i mężczyznami instrukcja nałożyła obowiązek wykazania jednoznacznych danych liczbowych potwierdzających brak takich nierówności. Ponadto dane te muszą być bezpośrednio powiązane ze specyfiką i/lub zakresem oddziaływania projektu. Dane te, podane w podziale na płeć, powinny nie tylko dotyczyć zasięgu oddziaływania projektu i obszaru interwencji projektu, lecz także odnosić się bezpośrednio do specyfiki grupy docelowej. Instrukcja dopuściła wykazanie danych z badań własnych, jednakże nałożyła obowiązek podania dokładnych informacji uwiarygodniających badania, tj. daty realizacji badania, wielkości próby badawczej oraz metodologii. Odnośnie do pytania czwartego, instrukcja zaleca szczególnie różnicowanie działań rekrutacyjnych oraz form wsparcia dla uczestników i uczestniczek. Jako podstawowy wymóg dla uzyskania odpowiedzi pozytywnej wskazuje podanie jednego przykładu działania, jakie zostanie zrealizowane w projekcie na rzecz wyrównywania nierówności i barier zdiagnozowanych w analizie sytuacji kobiet i mężczyzn lub działania zróżnicowanego pod kątem odmiennych potrzeb kobiet i mężczyzn. W celu uzyskania pozytywnej odpowiedzi na pytanie piąte, instrukcja zwraca uwagę na konieczność podania przynajmniej jednego rezultatu w podziale na płeć i/lub rezultatu wskazującego, jak projekt wpłynie na sytuację kobiet i mężczyzn w obszarze interwencji i/lub zasięgu oddziaływania projektu. Ponadto

s. 39; dostępne przez: http://www.efs.gov.pl/generatory_wnioskow/Documents/Instrukcja_luty2010_ver5_3_1.pdf (26.02.2013).

${ }_{16}$ Ibidem, s. 39-40. 
instrukcja zaleca uwzględnienie we wniosku informacji, co do sposobu, $\mathrm{w}$ jaki rezultaty te przyczynią się do zmniejszenia istniejących $\mathrm{w}$ obszarze interwencji i/lub zasięgu oddziaływania projektu nierówności ze względu na płeć.

Jako przykład równościowego zarządzania projektem instrukcja wskazuje przede wszystkim na konieczność uświadomienia osób zaangażowanych $\mathrm{w}$ realizację projektu w zakresie obowiązku przestrzegania zasady równości szans kobiet i mężczyzn. Za działanie z zakresu równościowego zarządzania może zostać uznane również zapewnienie zespołowi projektowemu takiej organizacji pracy, która umożliwia godzenie życia zawodowego z rodzinnym (np. elastyczne formy lub godziny pracy). Ponadto zaleca się różnicowanie zespołu projektowego pod względem płci w organach podejmujących decyzje w projekcie lub mających wpływ na jego przebieg (np. komitety, rady, komisje, grona partnerskie). Aby uzyskać pozytywną odpowiedź na pytanie szóste, wnioskodawca musi wskazać we wniosku minimum jedno działanie równościowe na rzecz zespołu projektowego ${ }^{17}$.

Podczas konferencji „Szanse i wyzwania dla równości szans płci w ramach Europejskiego Funduszu Społecznego na lata 2014-2020”, która odbyła się 6 lutego 2013 roku w Warszawie, przedstawiciele Ministerstwa Rozwoju Regionalnego przedstawili skwantyfikowane wskaźniki odnoszące się do wpływu środków z Europejskiego Funduszu Społecznego na sytuację kobiet i walkę z nierównościami. Do działań zrealizowanych w ramach projektów EFS należą m.in.:

- udzielnie dotacji na rozpoczęcie działalności gospodarczej dla ponad 52 tys. uczestniczek projektów;

- objęcie 154 tys. kobiet kontraktami socjalnymi w ramach projektów dotyczących aktywnej integracji i przeciwdziałaniu wykluczeniu społecznemu;

- objęcie ponad 14 tys. kobiet wsparciem w zakresie rozpoczynania własnej działalności gospodarczej typu spin-off lub spin out;

- ukończenie przez około 304 tys. kobiet pracujących szkoleń;

- objęcie wsparciem blisko 3,6 tys. ośrodków wychowania przedszkolnego,

- objęcie 110,5 tys. dzieci w wieku 3-5 lat różnymi formami edukacji przedszkolnej na obszarach wiejskich.

W zakresie osiągniętych efektów i oddziaływania projektów EFS wykazano, że:

- dzięki uczestnictwu w projektach PO KL ryzyko bezrobocia wśród kobiet zmniejszyło się o 21,2 proc.;

- 49 proc. kobiet w ciągu pierwszych 6 miesięcy od udziału w projekcie znalazło zatrudnienie (wśród mężczyzn wskaźnik wyniósł 66 proc.);

${ }^{17}$ Ibidem, s. 40-42. 
- u pracujących kobiet rzadziej niż wśród mężczyzn nastąpił wzrost dochodów w wyniku wsparcia (podwyżkę otrzymało 30 proc. mężczyzn i 20 proc. kobiet), ale po upływie dwóch lat od zakończenia wsparcia sytuacja uczestniczek projektów na rynku pracy uległa poprawie, a obserwowany uprzednio dystans w stosunku do mężczyzn (tzw. gender gap) się zmniejszył - różnica wynosiła już tylko 2 proc.;

- 15 proc. badanych urzędników instytucji, które wdrażają PO KL (Instytucje Pośredniczące i Instytucje Pośredniczące II stopnia) stwierdziło, że w ostatnich 3 latach w ich instytucji nastąpiły pozytywne zmiany w kwestii podejścia do równości szans płci ${ }^{18}$;

- możliwym jest diagnoza licznych dobrych praktyk z zakresu godzenia życia zawodowego z prywatnym wdrożonych przez urzędy w stosunku do swoich pracowników ${ }^{19}$;

- dzięki przeprowadzonej przez MRR kampanii informacyjnej na temat równości szans płci (spot reklamowy) 43 proc. osób badanych zapoznało się z prawami przysługującymi pracownikom w miejscu pracy, zaś dla 49 proc. osób był to pretekst do przyjrzenia się, czy zasada równości szans płci jest przestrzegana w ich miejscu pracy ${ }^{20}$.

\section{Jako przyczyny wprowadzenia w 2009 roku standardu minimum Mini-} sterstwo Rozwoju Regionalnego wymieniło:

- niedostateczną wiedzę na temat zasady równości szans kobiet i mężczyzn na poziomie instytucji i projektodawców - traktowanie jej jako udział 50/50;

- niezrozumienie zasady równości szans kobiet i mężczyzn oraz brak umiejętności przełożenia zasady na praktykę projektową;

- brak sposobu weryfikacji spełniania zasady, traktowanie jej jedynie jako wymogu formalnego ${ }^{21}$.

Korzyści z wprowadzenia standardu minimum, które wskazuje MRR, obejmują:

- zdefiniowanie elementów wniosku o dofinansowanie, których uwzględnienie oznacza spełnienie zasady równości szans kobiet i mężczyzn;

- umożliwienie jednoznacznej, zobiektywizowanej oceny wniosków - ujednolicenie decyzji Komisji Oceny Projektów;

- ułatwienie formułowania uzasadnień dla podejmowanych przez KOP decyzji ${ }^{22}$.

${ }^{18}$ Stosowanie zasady równości szans plci w ramach Programu Operacyjnego Kapitat Ludzki - dotychczasowe doświadczenia, prezentacja na konferencji pt. „Szanse i wyzwania dla równości szans płci w ramach Europejskiego Funduszu Społecznego na lata 2014-2020”, Ministerstwo Rozwoju Regionalnego, 6 lutego 2013; dostępne przez: http://www.efs.gov.pl/ wiadomosci/Strony/EFS_na_rzecz_rownosci_plci_o60213.aspx (26.02.2013).

19 Badanie wskaźnika Gender Index $w$ ramach instytucji zaangażowanych we wdrażanie PO KL. Raport końcowy ogólny, Ministerstwo Rozwoju Regionalnego, Warszawa 2011, s. 63-88.

${ }^{20}$ Stosowanie zasady..., op. cit.

${ }^{21}$ Ibidem.

${ }^{22}$ Wdrażanie równości szans ptci w projektach PO KL - wyzwania na przyszłość, prezentacja na konferencji pt. „Szanse i wyzwania dla równości szans płci w ramach Europejskiego Funduszu Społecznego na lata 2014-2020”, Ministerstwo Rozwoju Regionalnego, 6 lutego 
Z perspektywy czterech lat MRR wskazało również na planowe i pozytywne rezultaty wdrażania standardu minimum, tj.:

- podniesienie świadomości dotyczącej równości szans płci wśród oceniających i projektodawców;

- rozpoczęcie szerokiej dyskusji na temat równości szans płci w kontekście rynku pracy;

- zorganizowanie licznych szkoleń, spotkań informacyjnych, włączenie modułu dotyczącego równości szans płci w obowiązkowe szkolenia dla osób oceniających projekty ${ }^{23}$.

- Jednakże zauważono również nieplanowane i niepozytywne rezultaty, tj.:

- automatyczne podejście do spełniania wymogu standardu minimum;

- ograniczanie się przez projektodawców jedynie do umieszczania we wniosku minimalnych informacji wymaganych w standardzie do uzyskania dwóch pozytywnych odpowiedzi ${ }^{24}$.

Analizując wprowadzony standard minimum równości szans kobiet i mężczyzn oraz historię jego zmian, tj. pewnej liberalizacji wymagań oraz zaniechanie procesu zwiększania liczby wymaganych pozytywnych odpowiedzi po roku 2010, można stwierdzić, iż otoczenie instytucjonalne i osobowe Europejskiego Funduszu Społecznego w Polsce nie było gotowe na tak daleko idące rozwiązania. Opracowanie wniosku o dofinansowanie projektu, nawet przed wprowadzeniem standardu minimum, przez wielu projektodawców uważane było za skomplikowane i wymagające znajomości wielu dokumentów. Dodatkowo, zabrakło wśród nich szerokiej i powszechnej świadomości skali nierówności płci występującej na przykład na rynku pracy oraz potrzeby działań prorównościowych. Wprowadzenie standardu minimum zostało zatem odebrane jako narzucenie kolejnego obowiązku biurokratycznego. Ponieważ było to nowe zobowiązanie, początkowo projektodawcom brakowało wiedzy i umiejętności niezbędnych do jego wypełnienia. Stąd też bardzo duża liczba odrzuconych wniosków w pierwszych konkursach ogłoszonych po wprowadzeniu standardu minimum. Po pewnym czasie projektodawcy nauczyli się poprawnie konstruować zapisy wniosków, co nie oznacza jednak, że projekty zaczęły mieć charakter równościowy. Jak wskazuje MRR, w dużej mierze projektodawcy wyspecjalizowali się technicznie w konstruowaniu wniosku w sposób, który umożliwia uzyskanie minimum dwóch pozytywnych odpowiedzi w standardzie minimum. (Najczęściej jest to punkt dotyczący równościowego zarządzania projektem oraz wykazanie jednego rezultatu w podziale na płeć.) Zatem należy stwierdzić, iż wprowadzenie standardu nie zapewniło pełnego wdrożenia równości

2013; dostępne przez: http://www.efs.gov.pl/wiadomosci/Strony/EFS_na_rzecz_rownosci_plci_060213.aspx (26.02.2013).

${ }_{23}$ Ibidem.

24 Ibidem. 
szans kobiet i mężczyzn w projektach Europejskiego Funduszu Społecznego. Jednocześnie standard ten z pewnością miał wpływ na zwiększenie wśród projektodawców świadomości istnienia kwestii nierówności, dyskryminacji i konieczności prowadzenia działań prorównościowych. Wpłynął również na to, iż część realizowanych projektów nabrała równościowego charakteru. Niestety nadal można obserwować realizację projektów, które nie tylko nie wdrażają działań prorównościowych, ale powielają stereotypy. Przykładem może być nad wyraz częste stosowanie sylwetek mężczyzn i męskich form w nazwach przy promocji szkoleń w zawodach uważanych za stereotypowo męskie (np. zarządzanie przedsiębiorstwem, informatyka). Jednocześnie na plakatach i ulotkach zapraszających, na przykład, na szkolenia z zakresu opieki nad osobami starszymi, florystyki czy kadr najczęściej wykorzystywane są wizerunki kobiet.

Podsumowując, pozytywnie należy ocenić sam fakt wprowadzenia standardu oraz deklaracje Ministerstwa Rozwoju Regionalnego dotyczące jego funkcjonowania i ewentualnego wzmacniania w przyszłym okresie programowania, tj. w latach 2014-2020. Jednocześnie w przyszłej perspektywie należałoby rozważyć wprowadzenie rozwiązań, które minimalizowałby możliwości tzw. pozornej realizacji idei równych szans kobiet i mężczyzn w wybranych do dofinansowania projektach. Należy również szeroko informować o istniejących nierównościach i przejawach dyskryminacji ze względu na płeć oraz promować równość szans i uświadamiać w tym zakresie nie tylko projektodawców, ale również grupy docelowe projektów.

\section{BIBLIOGRAFIA}

Badanie wskaźnika Gender Index $w$ ramach instytucji zaangażowanych we wdrażanie PO KL. Raport końcowy ogólny, Ministerstwo Rozwoju Regionalnego, Warszawa 2011.

Gender Mainstreaming. Conceptual Framework, Methodology and Presentation of Good Practices, Council of Europe, Strasburg 1998.

Podręcznik przygotowania wniosków o dofinansowanie projektów w ramach PO KL z dnia 1 kwietnia 2009 roku, Ministerstwo Rozwoju Regionalnego, Warszawa 2009.

Program Operacyjny Kapital Ludzki. Narodowe Strategiczne Ramy Odniesienia 2007-2013, Ministerstwo Rozwoju Regionalnego, Warszawa 2007.

Wdrażanie równości szans ptci w projektach PO KL - wyzwania na przysztość, prezentacja na konferencji pt. „Szanse i wyzwania dla równości szans płci w ramach Europejskiego Funduszu Społecznego na lata 2014-2020", Ministerstwo Rozwoju Regionalnego, 6 lutego 2013; dostępne przez: http://www.efs.gov.pl/wiadomosci/Strony/EFS_na_ rzecz_rownosci_plci_060213.aspx (26.02.2013). 
Wniosek o dofinansowanie projektu: Program Operacyjny Kapitat Ludzki. Instrukcja (Instrukcja do wniosku o dofinansowanie v 5.3.1), Ministerstwo Rozwoju Regionalnego; dostępne przez: http://www.efs.gov.pl/generatory_wnioskow/Documents/Instrukcja_luty2010_ver5_3_1.pdf (26.02.2013).

Zasady dokonywania wyboru projektów w ramach Programu Operacyjnego Kapital Ludzki z dnia 1 kwietnia 2009 roku, Ministerstwo Rozwoju Regionalnego, Warszawa 2009.

Zasady dokonywania wyboru projektów w ramach Programu Operacyjnego Kapitał Ludzki z dnia 1 stycznia 2010 roku, Ministerstwo Rozwoju Regionalnego, Warszawa 2010. 